\title{
Occurrence of Antibiotic Resistant Bacteria in Pond Water Associated with Integrated Poultry-Fish Farming in Bangladesh
}

\author{
(Kejadian Bakteria Rintangan Antibiotik dalam Air Kolam Takungan yang Berkaitan
} dengan Penternakan Ayam-Ikan Bersepadu di Bangladesh)

\author{
FARZANA ASHRAFi NEELA*, MST. NASRIN AKHTER BANU, MD. ATIQUR RAHMAN, \\ M. HABIBUR RAHMAN \& M. FIROZ ALAM
}

\begin{abstract}
The use of antibiotics in poultry feed can cause antibiotic resistance in integrated poultry-fish farming pond environment. Therefore, the goal of this study was to monitor the prevalence of drug-resistant bacteria in pond water associated with poultry-fish farming in Bangladesh. The results showed that the prevalence rate of tetracycline (TC) and ampicillin (AMP) resistant bacteria were 0.24 to $2.59 \%$ and 0.16 to $1.0 \%$, respectively. The higher prevalence rate of TC and AMP-resistant bacteria was found in site 3 followed by site 4 and 2 compared with control site 1. Site 2, 3 and 4 were adjacent to the integrated poultry farm. On the other hand, higher TC and AMP-resistant bacteria were found in the rainy season than in the winter. The minimum inhibitory concentration result showed quite high level of TC and AMP-resistant bacterial distribution in the pond water. Seven genera of resistant bacteri; a were identified in pond water samples by $16 S$ rRNA gene analysis. Among them Acinetobacter sp. was predominant followed by Enterococcus sp., Pseudomonas sp., Bacillus, Staphylococcus sp., Enterobacter sp. and Brevibacillus sp.
\end{abstract}

Keywords: Antibiotics; integrated fish farm; poultry; resistant bacteria

\section{ABSTRAK}

Penggunaan antibiotik dalam makanan ayam boleh menyebabkan penentangan antibiotik dalam persekitaran kolam penternakan bersepadu ternakan ikan. Oleh itu, matlamat kajian ini adalah untuk memantau kekerapan bakteria rintangan drug dalam air kolam yang berkaitan dengan ternakan ikan ternakan di Bangladesh. Keputusan menunjukkan bahawa kadar prevalens tetrasiklin (TC) dan bakteria rintangan ampisilin (AMP) masing-masing adalah 0.24 kepada $2.59 \%$ dan 0.16 kepada 1.0\%. Kadar kelaziman bakteria TC dan rintangan-AMP yang tinggi didapati dalam tapak 3 yang diikuti oleh tapak 4 dan 2 berbanding dengan kawalan tapak 1. Tapak 2, 3 dan 4 adalah bersebelahan dengan ladang ayam bersepadu. Selain itu, bakteria TC dan rintangan-AMP yang lebih tinggi ditemui dalam musim hujan daripada pada musim sejuk. Hasil kepekatan rencatan minimum menunjukkan tahap yang agak tinggi untuk pengagihan bakteria TC dan rintangan-AMP di dalam air kolam. Tujuh genus bakteria rintangan dikenal pasti dalam sampel air kolam oleh analisis gen 16 rRNA. Antaranya Acinetobacter $s p$. adalah pradominan diikuti oleh bakteria Enterococcus sp., Pseudomonas sp., Bacillus, Staphylococcus sp., Enterobacter $s p$. dan Brevibacillus $s p$.

Kata kunci: Antibiotik; bakteria rintangan; kolam ikan bersepadu; ayam

\section{INTRODUCTION}

Antibiotic resistance has become one of the serious obstacles to the successful treatment of bacterial diseases. Resistance to antimicrobial agents is widespread and occurs in numerous bacterial genera (Chopra \& Robets 2001). Antibiotic resistance has been detected in various environments (Aarestrup et al . 2000; Kim et al. 2004; Neela et al. 2012, 2007; Rahman et al. 2008) including aquatic environment. Aquatic environment can play a vital role for harboring and dissemination of antibiotic resistance in various ecosystems (Depaola et al. 1995; Furushita et al. 2003). Peterson et al. (2002) reported that integrated poultry-fish farming is one of the major path-ways for accelerated spreading antibiotic resistance in aquatic environment.
Integrated poultry-fish farming, which was initiated in South Asia (Petersen et al. 2002) is now popular in Bangladesh. Because of its low cost and high yield, it is considered as a profitable business of farming (Hoa et al. 2008). This system involves chicken in cages located above or adjacent to fish ponds. It is presume that feces from chicken cage is introduced into the ponds, which is directly eaten by the fish or remain in ponds and stimulates the growth of plankton that is then eaten by the fish (Little \& Muir 1987). Chicken is normally reared intensively in this system by the use of commercial feed supplemented with antibiotics such as tetracycline, ampicillin and amoxicilin. These were used for growth promotion and prevention of diseases (Rahman \& Samad 2004). The chicken feces with residual antibiotics directly enter the fish pond which 
can create selective pressure on the aquatic microbes for selecting antibiotic resistant bacteria (Petersen \& Dalsgaard 2002). High prevalence of antimicrobial resistant bacteria and the resistance determinants have been detected in fish ponds of integrated aquaculture-agriculture in Thailand (Petersen \& Dalsgaard 2002) and Vietnam (Hoa et al. 2008). However, information is unavailable on the occurrence of antibiotic resistant bacteria in pond water associated with integrated poultry-fish farm in Bangladesh. Therefore, this study was carried out to monitor the occurrence of drug-resistant bacteria in pond water associated with poultry-fish farming in Bangladesh. The results of this study will provide scientific information on the present status of antibiotic resistant bacteria in aquatic environment of Bangladesh.

\section{MATERIALS AND METHODS \\ SAMPLING SITE AND SAMPLES}

Water samples were collected in two different seasons (winter and rainy) from four ponds in Puthia $\left(24^{\circ} 22^{\prime} 30^{\prime \prime} \mathrm{N}\right.$, $\left.88^{\circ} 51^{\prime} 0^{\prime \prime} \mathrm{E}\right)$ of Bangladesh, where three ponds were associated with poultry farms and another one was considered as control site (Site-1) which was not adjacent with poultry (Figure 1). Water samples were collected using a sterile bottle and placed in an icebox and transported to the laboratory for further experiment.

\section{VIABLE BACTERIAL COUNTS}

In order to enumerate viable bacteria, water samples were mixed with sterile phosphate buffered saline (PBS) and a 10 fold serial dilution was done. Plates were counted on nutrient broth plus $1.5 \%$ bacto $^{\mathrm{TM}}$ agar (BD and Co., Sparks, MD) containing $32 \mu \mathrm{g} / \mathrm{mL}$ of tetracycline (TC) and ampicillin (AMP), respectively. The media without antibiotics was considered as control. The plates were incubated at $25^{\circ} \mathrm{C}$ for 3 days. Duplicate counting was performed and colony forming unit $(\mathrm{CFU}) / \mathrm{mL}$ was calculated.

\section{MINIMUM INHIBITORY CONCENTRATION (MIC)}

Thirty eight isolates in winter and 40 isolates in rainy season were found resistant to $32 \mu \mathrm{g} / \mathrm{mL}$ of TC and AMP, respectively and were selected for determining resistance level by MIC assay. The MIC was determined by agar dilution method (Neela et al.2007). A bacterial cell suspension was prepared in PBS and cell density was adjusted to Macfarland No. 1.0. Ten microliters of bacterial cell suspension was spotted on nutrient agar medium containing 2-fold dilution of TC and AMP concentration of $0,16,32,64,128$ and 256 $\mu \mathrm{g} / \mathrm{mL}$, respectively. Plates were incubated at $25^{\circ} \mathrm{C}$ for 24

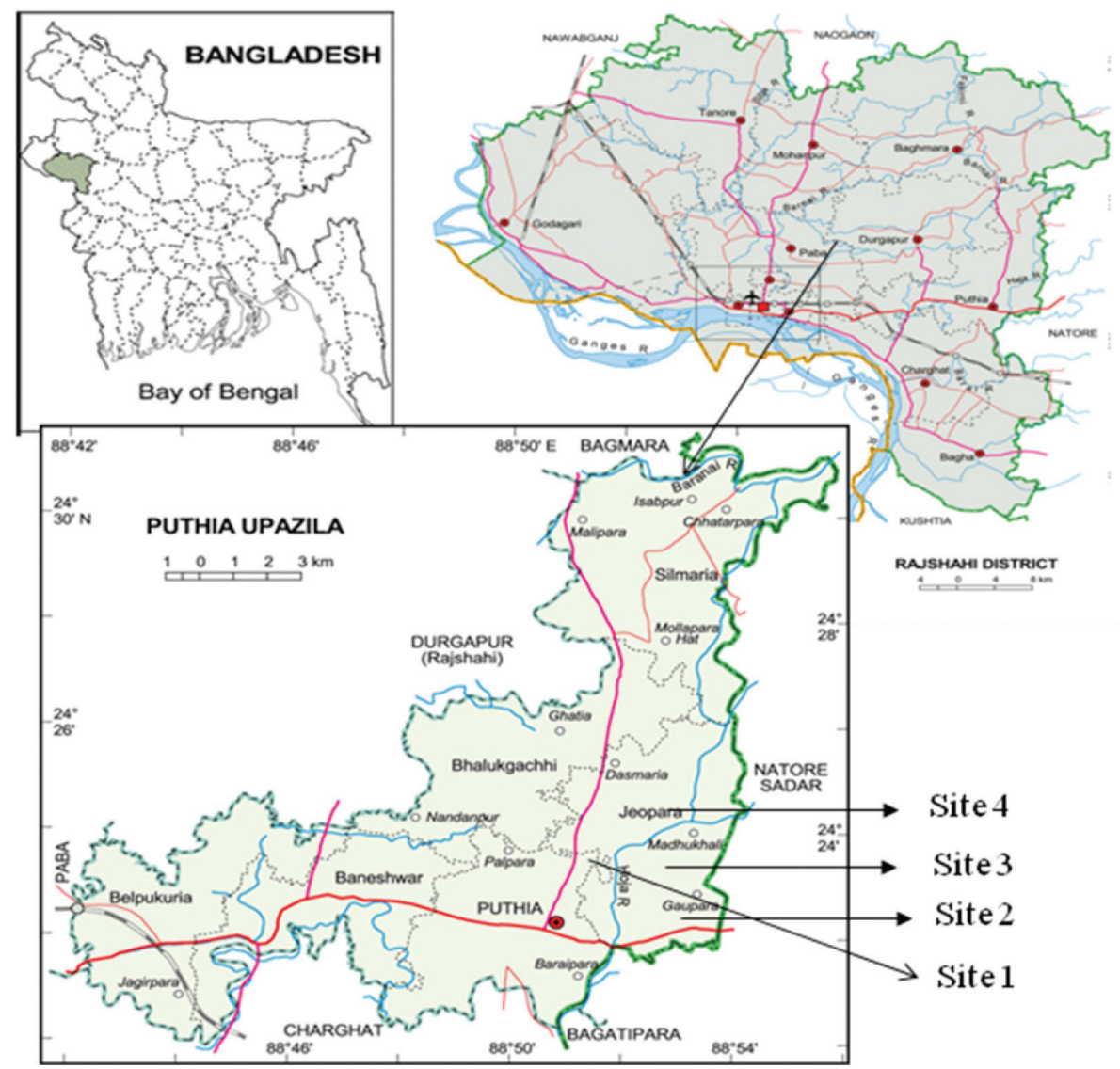

FIGURE 1. Sampling sites 
h. Resistance to an antibiotic was defined as $\geq 32 \mu \mathrm{g} / \mathrm{mL}$ (Walsh 2003).

\section{DNA EXTRACTION FROM ISOLATES}

A total of 35 antibiotic resistant strains randomly selected from both seasons (winter and rainy) were selected for DNA extraction. Resistant strains were cultured in nutrient broth at $25^{\circ} \mathrm{C}$ for $24 \mathrm{~h}$ with shaking. Cells were harvested by centrifugation at $3000 \times \mathrm{g}$ for $10 \mathrm{~min}$ and the DNA was extracted according to Rahman et al. (2008). Cells were suspended in $100 \mu \mathrm{L}$ of lysozyme (Sigma, USA) solution containing $10 \mu \mathrm{g}$ lysozyme in $10 \mathrm{mM}$ Tris- $\mathrm{HCl}$ (pH8.0). This was incubated at room temperature for $15 \mathrm{~min}$. One hundred $\mu \mathrm{L}$ of isolated solution containing $1 \mathrm{M} \mathrm{NaCl}, 0.5 \mathrm{M}$ EDTA, $10 \mathrm{mg} / \mathrm{mL}$ RNase A and 20\% SDS was added to the mixture and mixed well gently. The mixture was incubated at $65^{\circ} \mathrm{C}$ for $10 \mathrm{~min}$ and then $500 \mu \mathrm{L}$ of a solution containing $1 \mathrm{M} \mathrm{NaCl}, 0.1 \mathrm{M}$ EDTA and $0.5 \%$ SDS was added to the mixture and mixed well by inversion. DNA was purified by extraction with phenol saturated TE buffer (10 mM Tris$\mathrm{HCl}$, pH8.0 and $1 \mathrm{mM}$ EDTA) then with TE saturated phenol: chloroform:iso-amyl alchohol (25:24:1, v/v/v) and finally with chloroform. Final preparation of DNA was dissolved in TE (10 mM Tris-HCl, pH8.0, 1 mM EDTA) buffer and stored at $-20^{\circ} \mathrm{C}$ for further experiments.

\section{IDENTIFICATION OF RESISTANT BACTERIA}

A total of 18 resistant strains were considered for classification by $16 \mathrm{~S}$ rRNA gene analysis. Polymerase chain reaction (PCR) amplification of $16 \mathrm{~S}$ rRNA gene was performed using the set of primers of 10f (5'-AGTTTGATCCTGGCTCAG -3') and r907 (5'-CCGTCAATTCCTTTRAGTTT-3'). The PCR amplification was performed with a PCR Thermal Cycler Dice (TaKaRa, Shuzo Co. Japan). Reaction mixture for PCR contained $1 \times$ Ex Taq reaction buffer (TaKaRa, Otsu, Japan), $2 \mu \mathrm{L}$, each of $0.2 \mathrm{mM}$ dNTP, 25 pmol of each primer, $0.62 \mathrm{U}$ of Ex Taq DNA polymerase (TaKaRa, Otsu, Japan) and 20-90 ng of template DNA in a final volume of $25 \mu \mathrm{L}$. PCR cycles consisted of initial denaturing at $95^{\circ} \mathrm{C}$ for $2 \mathrm{~min}$, denaturing at $95^{\circ} \mathrm{C}$ for $30 \mathrm{~s}$, annealing at $54^{\circ} \mathrm{C}$ for $45 \mathrm{~s}$ and elongation at $72^{\circ} \mathrm{C}$ for $1.30 \mathrm{~min}$. The reaction was performed for 22 cycles. Five $\mu \mathrm{L}$ of PCR product was analyzed on electrophoresis of a $1.5 \%(\mathrm{w} / \mathrm{v})$ agarose gel. Gels were stained with ethidium bromide and visualized on an Epi-Light UV FA1100 system with a luminous Imager version 2.0 (Aisin Cosmos R\&D, Aichi, Japan). The PCR products of $16 \mathrm{~S}$ rRNA was purified by ethanol precipitation and sequencing were performed for both strands with a BigDye Terminater version 3.1 cycle sequencing kit (Applied Biosystems, Foster City, CA, USA) by a $3130 \times$-AB1 PRISM DNA sequencer (Applied Biosystems, Foster City, CA, USA). On-line similarity searching was performed using the Basic Local Alignment Search Tool (BLAST) at the National Center for Biotechnology Information web site (NCBI, http://www. ncbi.nlm.nih.gov/).

\section{PLASMID EXTRACTION}

Plasmid DNA was extracted using a QIAGEN plasmid kit (Qiagen, USA) according to the manufacturer's instruction. A single bacterial colony was picked-up and grown in $5.0 \mathrm{~mL}$ nutrient broth at $25^{\circ} \mathrm{C}$ for overnight. The cell suspension was transferred to $1.5 \mathrm{~mL}$ eppendorf tube and centrifuged at $13000 \mathrm{rpm}$ for $3 \mathrm{~min}$. The cell pellets were re-suspended in $0.3 \mathrm{~mL}$ of buffer $\mathrm{P} 1$. Then added $0.3 \mathrm{~mL}$ of buffer P2, mixed thoroughly by vigorously inverting the sealed tube 4 to 6 times and incubated at room temperature for $5 \mathrm{~min}$. Then added $0.3 \mathrm{~mL}$ of chilled buffer P3 and mixed immediately by vigorously inverting 4 to 6 times. The mixture was incubated on ice for $5 \mathrm{~min}$. After that, centrifuged at maximum speed in a microcentrifuge for 10 min. Supernatant containing plasmid DNA was removed promptly. $1 \mathrm{~mL}$ of QBT buffer was applied to a QIAGEN-tip 20 for equilibration and allowed the column to be empty by gravitational flow. The supernatant from step 7 was applied to QIAGEN-tip 20 and allowed it to enter by gravity flow for risen. The QIAGEN-tip 20 was washed with $2 \times 2 \mathrm{~mL}$ buffer QC. DNA with $0.8 \mathrm{~mL}$ buffer QF was eluted. The eluted DNA was precipitated by adding 0.7 volumes $(0.56 \mathrm{~mL}$ per 0.8 of elution volume) of room-temperature isopropanol and mixed and centrifuged immediately at $>10000 \mathrm{rpm}$ for 30 min in a microcentrifuge. The supernatant was decanted carefully. DNA pellets were washed with $1 \mathrm{~mL}$ of $70 \%$ ethanol and centrifuged at $10000 \mathrm{rpm}$ for $10 \mathrm{~min}$. The supernatant was decanted without disturbing the pellet carefully. Finally, the pellet was air dried for $10 \mathrm{~min}$ and dissolved the DNA in $20 \mu \mathrm{L}$ TE buffer then stored at $-20^{\circ} \mathrm{C}$.

\section{RESULTS AND DISCUSSION}

It has been reported that antibiotic resistance has become a serious issue in various environments for human health concern (Neela et al. 2012; Rahman et al. 2008). It is also well demonstrated that aquatic environment can play a vital role for spreading of antibiotic resistant bacteria and resistance gene in various ecosystem (Neela et al. 2009). Neela et al. (2012) reported the occurrence of the antibiotic resistant bacteria in brackish and fresh water in Bangladesh. However, research on the monitoring of antibiotic resistance in aquatic environments of Bangladesh still scanty.

Water samples from pond associated with integrated poultry-fish farming in winter and rainy season were collected to enumerated antibiotic resistant bacteria. The viable bacterial number ranged from $(2.4 \pm 0.070) \times 10^{5}$ to $(2.3 \pm 0.070) \times 10^{6} \mathrm{CFU} / \mathrm{mL}$ and $(2.2 \pm 0.070) \times 10^{6}$ to $(3.9 \pm 0.141) \times 10^{6} \mathrm{CFU} / \mathrm{mL}$ in winter and rainy season, respectively (Table 1). The highest and lowest number of viable bacteria was found in site 1 (control) and site 3 , in winter and rainy season, respectively (Table 1 ). The occurrence rate of TC resistant bacteria $(32 \mu \mathrm{g} /$ $\mathrm{mL}$ ) was 0.74 to $1.21 \%$ in winter and 1.62 to $2.59 \%$ in rainy season among the total viable count. The highest TC resistant bacteria were found in the site 3 followed by site 2 and 4 which are located adjacent to chicken 
farm. It is interesting that site 1 showed low number of resistant bacteria compared to site 2, 3 and 4 suggesting that integrated poultry farming played a vital role for harboring TC resistant bacteria. Similar results have been reported by Petersen et al. (2002). They demonstrated that the level of resistance to drugs was significantly higher for the isolates from all manure samples suggesting that integrated poultry fish farm is a source for increased antibiotic resistance. High prevalence of antimicrobial resistant bacteria and resistance determinants has been detected in fish ponds of aquaculture (chicken-fish farm) in Thailand (Petersen \& Dalsgaard 2003). Thus, suggesting that the higher prevalence of resistant bacteria in site 3,2 , and 4 originated from poultry farm. In case of AMP resistant strains $(32 \mu \mathrm{g} / \mathrm{mL})$, the prevalence rate was 0.10 to $0.44 \%$ in winter and 0.27 to $1.10 \%$ in rainy season, respectively (Table 1 ).
This data showed quite higher number of TC and AMP resistant bacteria distributed in the pond associated with the integrated poultry-fish farming compared to brackish and freshwater in Bangladesh (Neela et al. 2012). Thus it can be suggested that poultry farm associated with integrated fish farm is one of the vital sources for harboring and spreading drug resistant bacteria in the aquatic ecosystem. On the other hand, high prevalence of TC and AMP resistant bacteria was recorded in the rainy season than in the winter (Figure 2). The differences in prevalence of resistant bacteria between rainy and winter season is statistically significant. Hoa et al. (2011) found high prevalence of antibiotic resistant bacteria in the rainy season than dry season in northern Vietnam. There is a similarity with the results of the present study.

It is fact that run-off water during rainy season is more dispersed and dynamic than that the winter season,

TABLE 1. Viable count of TC and AMP resistant bacteria in pond water associated with integrated poultry-fish farm

\begin{tabular}{lccc}
\hline Samples site & Total viable count & $\begin{array}{c}\text { TC resistant } \\
32 \mathrm{mg} / \mathrm{mL}(\%)\end{array}$ & $\begin{array}{c}\text { AMP resistant } \\
32 \mathrm{mg} / \mathrm{mL}(\%)\end{array}$ \\
\hline Season-Winter & & & \\
Site-1 & $(2.3 \pm 0.070) \times 10^{6}$ & $(1.7 \pm 0.141) \times 10^{4}(0.74)$ & $(7.2 \pm 0.494) \times 10^{3}(0.18)$ \\
Site-2 & $(2.0 \pm 0.070) \times 10^{6}$ & $(1.8 \pm 0.070) \times 10^{4}(0.86)$ & $(6.4 \pm 0.282) \times 10^{3}(0.16)$ \\
Site-3 & $(2.4 \pm 0.212) \times 10^{5}$ & $(2.9 \pm 0.141) \times 10^{3}(1.21)$ & $(6.1 \pm 0.141) \times 10^{3}(0.16)$ \\
Site-4 & $(2.1 \pm 0.070) \times 10^{6}$ & $(2.5 \pm 0.070) \times 10^{4}(1.18)$ & $(7.2 \pm 0.282) \times 10^{3}(0.18)$ \\
Season-Rainy & & & \\
Site-1 & $(3.9 \pm 0.141) \times 10^{6}$ & $(6.3 \pm 0.141) \times 10^{4}(1.62)$ & $(7.7 \pm 0.494) \times 10^{3}(0.33)$ \\
Site-2 & $(3.4 \pm 0.070) \times 10^{6}$ & $(6.4 \pm 0.565) \times 10^{4}(1.88)$ & $(6.7 \pm 0.212) \times 10^{3}(0.33)$ \\
Site-3 & $(2.2 \pm 0.070) \times 10^{6}$ & $(5.7 \pm 0.424) \times 10^{4}(2.59)$ & $(2.4 \pm 0.282) \times 10^{3}(1.00)$ \\
Site-4 & $(3.45 \pm 0.070) \times 10^{6}$ & $(8.0 \pm 0.282) \times 10^{4}(2.29)$ & $(9.6 \pm 0.070) \times 10^{3}(0.44)$ \\
\hline
\end{tabular}

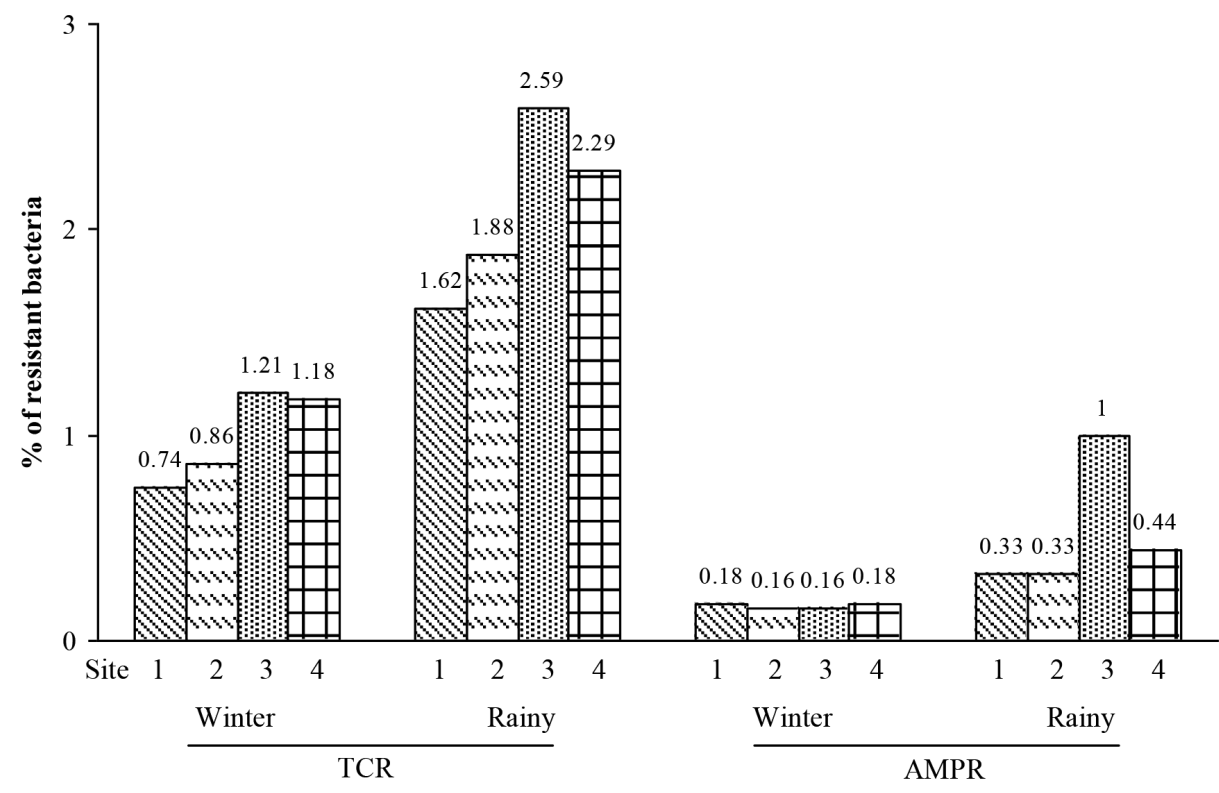

FIGURE 2. Occurrence rate of TC and AMP resistant bacteria in winter and rainy season. Difference of occurrence rate of resistant bacteria between winter and rainy season statistically significant $(p<0.05)$ 
suggesting that mixing of bacterial species from soil, anthropogenic sources and aquatic environments occurs mostly during rainy season. The mixing of various bacteria should accelerate horizontal gene transfer in the microbial ecosystem suggesting a greater risk of spreading harmful bacteria (Gurdabassi et al. 2000; Hoa et al. 2008; Neela et al. 2009). Chee-Sanford et al. (2001) reported that TC resistance genes could be spread from swine farms to downstream areas via groundwater. It is therefore important to consider groundwater as an effective carrier of drug resistant bacteria.

We selected resistant bacteria 38 from winter and 40 from rainy season, at $32 \mu \mathrm{g} / \mathrm{mL}$ of TC and AMP for MIC assay (Table 2). Among 38 strains from winter water samples, 97.4.2, 26.3, 15.8 and $0.0 \%$ of strains showed resistance against $32,64,128$ and $256 \mu \mathrm{g} / \mathrm{mL}$ of TC and 100, 23.7, 13.2 and $0.0 \%$ strains were found to be resistant against 32 , 64, 128 and $256 \mu \mathrm{g} / \mathrm{mL}$ of AMP, respectively. In the case of 40 strains from rainy water samples, the percentage of TC resistant isolates were 100, 30.0, 12.5, 0.0\% and AMP resistant isolates were $92.5,25,20$ and $5 \%$, respectively (Table 2). In the case of both TC-AMP resistant, 50, 15.7, $13.2,0 \%$ and $52.5,20,15$ and $0 \%$ were found resistant to $32,64,128$ and $256 \mu \mathrm{g} / \mathrm{mL}$ in winter and rainy season, respectively (Table 2 ).

In this study, more isolates could be detected, but the strains which were resistant to $>32 \mu \mathrm{g} / \mathrm{mL}$ of antibiotics; were considered resistant bacteria. Because, earlier study reported that for environmental samples, the bacteria which are resistant to at least $32 \mu \mathrm{g} / \mathrm{mL}$ can be considered as resistant strain (Neela et al. 2007; Walsh 2003). We found a high number of isolates which were resistant to 32-128 $\mu \mathrm{g} / \mathrm{mL}$ of TC and AMP. This data suggests that high level of TC and AMP resistant bacteria were distributed in the aquatic environment in Bangladesh. A previous study (Sayah et al. 2005) reported the TC resistance in a high level of multi-drug resistant $E$. coli isolates in various domestic animal species and farm environments, which suggests that having resistance to various antibiotics can relate specifically to TC resistance. Therefore, TC or AMP resistance might increase the risk of becoming resistant to additional drugs. Similarly, our results suggest that there may be linkage between TC-resistance and resistance to other drugs.
To classify the resistant bacteria, we selected 18 strains from water which were resistant to TC and AMP. The 16S rRNA analysis showed that Acinetobacter sp. $22.22 \%(4 / 18)$ was dominant in freshwater followed by Enterococcus sp., Pseudomonas sp., Bacillus sp., Staphylococcus sp. 16.67\% (3/18), Enterobacter sp. and Brevibacillus $5.55 \%$ (1/18) (Table 3).

The classified bacterial isolated showed a large variety of resistant bacteria in the investigated pond, which could be the sources for acceleration of resistant bacteria in the various environments in Bangladesh. In this study we did not detect resistance genes but it is obvious that the presence of resistance gene in the isolates is responsible for their resistance to drugs. Roberts (2005) reported that until now 42 genes have been detected in numerous bacterial genera which are responsible for bacterial resistance to drugs.

In this study, we found some TC or AMP resistant bacteria that possessed plasmid (Table 3). Antibiotic resistance is often accompanied with plasmids and transposons, contributing to the wide distribution of this gene in bacterial genera obtained from different environments by horizontal gene transfer (Chopra \& Roberts 2001). Neela et al. (2009) reported that resistance gene can be transferred from resistant bacteria to susceptible bacteria by genetic elements like plasmids or transposons. Thus it can be suggested that resistant bacteria can increase in the wide area of aquatic environments in Bangladesh.

\section{CONCLUSION}

In conclusion, these results suggested that aquatic environments associated with integrated poultry farms in this region could be consider as a reservoir for the antibiotic resistant bacteria.

\section{ACKNOWLEDGEMENTS}

The authors are thankful to the Department of Botany, Rajshahi University, Bangladesh for providing necessary facilities. The authors are also expressing their appreciation to Professor Hiroyuki Ohta, ETC Laboratory, Faculty of

TABLE 2. Minimum inhibitory concentration level of resistant bacteria

\begin{tabular}{lcccccccc}
\hline \multirow{2}{*}{ Season } & Antibiotics & $\begin{array}{c}\text { No. of strain } \\
\text { examined }\end{array}$ & 0 & 16 & 32 & 64 & 128 & 256 \\
\hline \multirow{2}{*}{ Winter } & TC & 38 & $38(100 \%)$ & $38(100 \%)$ & $37(97.4 \%)$ & $10(26.3 \%)$ & $6(15.8 \%)$ & $0(\%)$ \\
& AMP & 38 & $38(100)$ & $38(100)$ & $38(100)$ & $9(23.7)$ & $5(13.2)$ & 0 \\
& TC-AMP & 38 & $38(100)$ & $38(100)$ & $17(50)$ & $6(15.7)$ & $5(13.2)$ \\
\multirow{5}{*}{ Rainy } & & & & & & & \\
& & & & & & & \\
& TC & 40 & $40(100)$ & $40(100)$ & $40(100)$ & $12(30)$ & $5(12.5)$ & 0 \\
& AMP & 40 & $40(100)$ & $40(100)$ & $37(92.5)$ & $10(25)$ & $8(20)$ & $2(5.0)$ \\
& TC-AMP & 40 & $40(100)$ & $40(100)$ & $21(52.5)$ & $8(20)$ & $7(15)$ & 0 \\
\hline
\end{tabular}


TABLE 3. Identification of TC and AMP resistant bacteria by $16 \mathrm{~S}$ rRNA gene sequencing

\begin{tabular}{|c|c|c|c|c|c|c|}
\hline $\begin{array}{c}\text { Total } \\
\text { sequenced } \\
\text { isolates }\end{array}$ & Isolates ID & Closest relation & $\begin{array}{l}\text { Accession } \\
\text { number }\end{array}$ & $\begin{array}{l}\text { Similarity } \\
(\%)\end{array}$ & $\begin{array}{c}\% \text { of identified } \\
\text { isolates }\end{array}$ & $\begin{array}{c}\text { Presence of } \\
\text { plasmid }\end{array}$ \\
\hline \multirow[t]{18}{*}{18} & 280109WR04 & Acinetobacter sp. & EF204266 & 100 & & $\mathrm{nf}^{\mathrm{a}}$ \\
\hline & 050209WR12 & Acinetobacter sp. & EF204266 & 100 & & $\mathrm{nf}$ \\
\hline & 210709RR64 & Acinetobacter sp. & EF204266 & 100 & & $\mathrm{nf}$ \\
\hline & 140709RR49 & Acinetobacter sp. & GQ169068 & 95 & 4/18 (22.22) & $\mathrm{nf}$ \\
\hline & 280109WR03 & Enterococcus sp. & AY850358 & 97 & & $\mathrm{nf}$ \\
\hline & 170709RR54 & Enterococcus sp. & AY850358 & 97 & & $\mathrm{nf}$ \\
\hline & 210709RR67 & Enterococcus sp. & AY850358 & 97 & 3/18 (16.67) & $\mathrm{nf}$ \\
\hline & 280109WR06 & Psedomonas sp. & GQ867230 & 98 & & $\mathrm{nf}$ \\
\hline & 230709RR76 & Psedomonas sp. & GQ867230 & 98 & & $\mathrm{nf}$ \\
\hline & 170709RR57 & Psedomonas sp. & DQ201396 & 95 & $3 / 18(16.67)$ & $\mathrm{p}^{\mathrm{b}}$ \\
\hline & 120209WR23 & Bacillus sp. & GU217692 & 100 & & $\mathrm{p}$ \\
\hline & 280109WR23 & Bacillus sp. & EU867357 & 100 & & $\mathrm{p}$ \\
\hline & 050209WR20 & Bacillus sp. & FJ993045 & 100 & 3/18 (16.67) & $\mathrm{nf}$ \\
\hline & 120209WR26 & Staphylococcus sp. & EF173930 & 99 & & $\mathrm{p}$ \\
\hline & 140709RR41 & Staphylococcus sp. & EF173930 & 100 & & $\mathrm{p}$ \\
\hline & 140709RR48 & Staphylococcus sp. & EF204306 & 100 & 3/18 (16.67) & $\mathrm{nf}$ \\
\hline & 140709RR48 & Enterobacter sp. & GQ383912 & 97 & $1 / 18(5.55)$ & $\mathrm{p}$ \\
\hline & 230709RR73 & Brevibacillus sp. & GQ927168 & 99 & $1 / 18(5.55)$ & $\mathrm{nf}$ \\
\hline
\end{tabular}

${ }^{a}$ : not found

${ }^{\mathrm{b}}:$ plasmid presence

Agriculture, Ibaraki University, Japan for allowing access to their facilities for sequencing.

\section{REFERENCES}

Aarestrup, F.M., Agerso, Y., Gerner-Smidt, P., Madsen, M. \& Jensen, LB. 2000. Comparison of antimicrobial resistance phenotypes and resistance genes in Enterococcus faecalis and Enterococcus faecium from humans in the community, broilers, and pigs in Denmark. Diagnostic Microbiology and Infectious Disease 37(2): 127-137.

Chee-sanford, J.C., Aminov, R.I., Krapac, I.J., Garrigues-Jean, N. \& Mackie, R.I. 2001. Occurrence and diversity of tetracycline resistance genes in lagoons and groundwater underlying two swine production facilities. Applied and Environmental Microbiology 67(4): 1494-1502.

Chopra, I. \& Roberts, M. 2001. Tetracycline antibiotics: Mode of action, applications, molecular biology, and epidemiology of bacterial resistance. Microbiology and Molecular Biology Reviews 65(2): 232-260.

DePaola, A., Peeler, J.T. \& Rodrick, G.E. 1995. Effect of oxytetracycline-mediated feed on antibiotic resistance of Gram-negative bacteria in catfish ponds. Applied and Environmental Microbiology 61(6): 2335-2340.

Furushita, M., Shiba, T., Maeda, T., Yahata, M., Kaneoka, A., Takahashi, Y., Torii, K., Hasegawa, T. \& Ohta, M. 2003. Similarity of tetracycline resistance genes isolated from fish farm bacteria to those from clinical isolates. Applied and Environmental Microbiology 69(9): 5336-5342.
Guardabassi, L., Dijkshoorn, L., Collard, J.M., Olsen, J.E. \& Dalsgaard, A. 2000. Distribution and in vitro transfer of tetracycline resistance determinants in clinical and aquatic Acinetobacter strains. Journal of Medical Microbiology 49(10): 929-936.

Hoa, P.T.P., Managaki, S., Nakada, N., Takada, H., Shimizu, A., Anh, D.H., Viet, P.H. \& Suzuki, S. 2011. Antibiotic contamination and occurrence of antibiotic resistant bacteria aquatic environments of northern Vietnam. Science of the Total Environment 409: 2894-2901.

Hoa, P.T.P., Nonaka, L., Viet, P.H. \& Suzuki, S. 2008. Detection of the sul1, sul2, and sul3 genes in sulfonamide-resistant bacteria from wastewater and shrimp ponds of north Vietnam. Science of the Total Environment 405(1): 377-384.

Kim, S.R., Nonaka, L. \& Suzuki, S. 2004. Occurrence of tetracycline resistance genes $\operatorname{tet}(\mathrm{M})$ and $\operatorname{tet}(\mathrm{S})$ in bacteria from marine aquaculture sites. FEMS Microbiology Letters 237(1): 147-156

Little, D. \& Muir, J. 1987. A Guide to Integrated Warm Water Aquaculture. University of Stirling: Institute of Aquaculture Publications.

Neela, F.A., Rahman, M.A., Banu, M.N.A., Rahman, M.H., Ohta, H. \& Alam, M.F. 2012. Occurrence of two antibiotic resistant bacteria in aquatic environment associated with shrimp farming in Bangladesh. Bangladesh Journal of Botany 41(2): 197-200

Neela, F.A., Nonaka, L., Rahman, M.H. \& Suzuki, S. 2009. Transfer of the chromosomally encoded tetracycline resistant gene tet(M) from marine bacteria to Escherichia coli and 
Enterococcus faecalis. World Journal of Microbiology and Biotechnology 25(6): 1095-1101.

Neela, F.A., Nonaka, L. \& Suzuki, S. 2007. The diversity of multi-drug resistance profiles in tetracycline-resistance Vibrio species isolated from coastal sediments and seawater. Journal of Microbiology 45(1): 64-68.

Petersen, A. \& Dalsgaard, A. 2002. Antimicrobial resistance of intestinal Aeromonas spp. and Enterococcus spp. in fish cultured in integrated broiler-fish farms in Thailand. Applied and Environmental Microbiology 68(12): 4908-4915.

Peterson, A., Andersen, J.S., Kaewmak, T., Somsiri, T. \& Dalsgaard, A. 2002. Impact of integrated fish farming on antimicrobial resistance in a pond environment. Applied and Environmental Microbiology 68(12): 6036-6042.

Rahman, M.H., Nonaks, L., Tago, R. \& Suzuki S. 2008. Occurrence of two genotypes of tetracycline (TC) resistance gene $\operatorname{tet}(\mathrm{M})$ in the TC-resistant bacteria in marine sediments of Japan. Environmental Science and Technology 42(14): 5055-5061.

Rahman, M.A. \& Samad, M.A. 2004. Important systemic and miscellaneous diseases associated with morbidity and mortality in commercial poultry in Bangladesh. Bangladesh Journal of Veterinary Medicine 2(1): 91-98.

Roberts, M.C. 2005. Update on acquired tetracycline resistance genes. FEMS Microbiology Letters 245(2): 195-203.

Sayah, R.S., Kaneene, J.B., Johnson, Y. \& Miller, R. 2005. Patterns of antimicrobial resistance observed in Escherichia coli isolates obtained from domestic-and wild-animal fecal samples, human septage, and surface water. Applied and Environmental Microbiology 71(3): 1394-1404.
Walsh, C. 2003. Antibiotics that block bacterial protein biosynthesis. In Antibiotics: Actions, Origins, Resistance. Washington D.C.: ASM Press.

Farzana Ashrafi Neela*, MST. Nasrin Akhter Banu, Md. Atiqur Rahman \&

M. Firoz Alam

Department of Botany, Rajshahi University

Rajshahi 6205

Bangladesh

M. Habibur Rahman

Department of Zoology, Rajshahi University

Rajshahi 6205

Bangladesh

*Corresponding author; email: nfarzanaashrafi@yahoo.com

Received: 14 July 2014

Accepted: 6 October 2014 